\title{
Discovering Values and Sense of Purpose Through Leadership Education
}

\author{
Kathy L. Guthrie \\ Florida State University \\ Vivechkanand Chunoo \\ University of Illinois at Urbana-Champaign \\ Allison B. Peters \\ Florida State University
}

Currently a movement toward a more holistic approach to student learning is occurring on college campuses. This is partly due to a focus on a more ethically conscious graduate. Educators are more aware and intentional about creating learning opportunities that consider values, sense of purpose, and leadership. The qualitative study in this article identifies how educators can and do influence values discovery and sense of purpose throughout college, specifically in the context of curricular-based leadership education. Findings from this study demonstrate how participants leveraged leadership learning in their post-college lives, as well as how the learning environment, integrating self and action through values discovery, and their sense of purpose is critical for students. Providing a space for value discovery and reflection on sense of purpose through leadership learning enhances students' academic studies.

Keywords: leadership education, values, academic curriculum, purpose

\section{INTRODUCTION}

There is an emphasis on leadership development programs in higher education; however, few institutions offer leadership programs as part of the formal curriculum (Cress et al., 2001). Recently, there has been a proliferation of co-curricular leadership programs on college campuses (Dugan, 2006; Thompson, 2006). However, research is scant on the models used in leadership education and the research on college student leadership (Dugan, 2006).

The educational significance of this study is to advance the existing body of knowledge in the field of student development, character education, and leadership education. Through this study, scholars have a stronger idea as to how students' values are discovered through their experiences in college, specifically from leadership coursework. This study assists leadership educators in teaching values; as, according to Northouse (2021), it is the responsibility of the leader to help followers evaluate their own values and needs to elevate each other to an increased level of functioning. The study identifies how educators can and do influence values discovery and sense of purpose throughout college.

To maximize the benefit of curricular leadership development programs, educators should include values-based conversations in the curriculum. The current paradigms of leadership education necessitate 
the development of both personal and social values in leaders (Cress et al., 2001). The Council for the Advancement of Standards in Higher Education (CAS) suggested, "leadership development involves engaging with learning opportunities in one's own environment... to build one's capacity or efficacy to engage in leadership. This developmental approach entails moving from simple to more complex dimensions of growth" (Komives et al., 2006, p. 402). Northouse (2021) agreed by emphasizing that leadership involves values and a leader cannot be unaware of their own values. Thompson (1991) echoed the importance of teaching moral responsibility, particularly to our leaders, encouraging "any institution which is concerned with the moral imperatives must teach responsibility, for responsibility is the other side of morality" (p. 4). With this in mind, the guiding research question for this study was "What do leadership certificate alumni learn from curriculum and experiences in the program? How do they use this in their current work?"

\section{LEADERSHIP LEARNING: VALUES AND SENSE OF PURPOSE}

Leadership learning and education has become a central piece of student development work at colleges and universities (Dugan, 2006; Thompson, 2006). As many institutions continue to infuse leadership, civic engagement, and character development into mission and vision statements, leadership development programs offer a space for formal and informal learning in these domains. To meet this goal, Astin and Astin (2000) recommend leadership learning and development programs focused on areas such selfknowledge, authenticity, empathy, commitment, competence, group projects, collaboration, shared purpose, division of labor, disagreement with respect, and an environment of learning. Leadership education is the broad understanding of leadership knowledge, skills, and values, which occurs both in and out-ofthe-classroom, a deep commitment to the teaching and learning of leadership knowledge, skills, and values with a longer duration in mind (Roberts, 2007). Leadership training is the acquisition of leadership skills and is often shorter in duration. Leadership development is the reflection and integration of leadership knowledge, skills, and values and leadership engagement is the application and practice of leadership knowledge, skills, and values. Leadership learning provides a context for constant discovery through the interaction between theory and practice (Guthrie \& Jenkins, 2018; Roberts, 2007). Leadership education programs utilize curricular and co-curricular learning environments to encourage students integrated, holistic leadership learning.

\section{Leadership Learning}

Leadership itself is a process of learning in which individuals make sense of their experiences, uncover leadership within themselves, and work in communities of leadership practice with others (Antonacopoulou \& Bento, 2004). Guthrie and Jenkins (2018) define leadership learning as "changes in knowledge, skills, behaviors, attitudes, and values resulting from educational experiences, both co-curricular and curricular in nature, associated with the activity of leadership" (p. 57). The leadership learning framework (Guthrie \& Jenkins, 2018) is an accessible model that includes the six aspects of knowledge, development, training, observation, engagement, and metacognition (Guthrie \& Jenkins, 2018). This model builds off Guthrie \& Osteen's (2012) four areas of leadership learning which includes education, training, development, and engagement. Both models expanded Roberts and Ullom's (1989) training, education, and development model.

Leadership skills and efficacy develop over time, influenced by active learning processes in which learners engage in development of "cognitive capacities, personality and temperament, ability to emotionally regulate, identities, and values that derive from both the cultural context and personal experience" (Lord \& Hall, 2005, p. 611). Lord and Hall (2005) found these capacities lead to self-regulation in the leadership process, as individuals begin to integrate their abilities and identities while interacting with others.

Leader development and leadership development are integrated into leadership learning. Distinguishing between these processes, Guthrie et al. (2013) clarify, "Leader development focuses on individual students' capacity and identity, with or without formal authority, to engage in the leadership process; while leadership 
development is a collective focus on a group's relationships and process" (p. 15). Leadership learning touches on both aspects of learning and development around leadership. Leadership learning is multifaceted, as individuals are influenced by their experiences in several arenas. Thus, assessing individual leadership learning and its connection to group processes of leadership has become a focus of leadership literature.

\section{Leadership Education}

Leadership education programs are prevalent on college campuses, occurring in formal learning environments and through short-term programs focused on development of leadership skills, theories, and applications. From an extensive literature review, Guthrie and Jenkins (2018) provided five characteristics for distinctive leadership programs. Distinctive programs have positive influence on student leadership learning and distinctiveness is based on high-quality programs that meet their stated learning outcomes. Eich (2008) proposed that high-quality leadership programs focus on opportunities for students to practice leadership in various ways. Building off Eich's (2008) work, Guthrie and Jenkins (2018) found five characteristics of distinctive leadership programs, including 1) intentionally designed programs; 2) authentic leadership learning environments; 3) application of knowledge, skills, and values; 4) meaning making through reflection; and 5) continuous program improvement. These characteristics for distinctive leadership education programs help establish leadership learning opportunities for students.

Both long- and short-term leadership education opportunities are available on college campuses and offer potential for leadership learning. Dugan and Komives (2007) found students who attend short-term leadership education programs reported higher growth in leadership outcomes than those who did not attend any sessions, a finding which was significant regardless of the number of educational sessions a student attended. However, long-term leadership education experiences such as leadership courses and on-going development programs were more impactful on measures of students' change navigation skills and leadership efficacy. Students who engaged in formal leadership programs of any length were found to have higher perceived growth in outcomes associated with group or societal values, reflecting the impact of leadership education on relational aspects of leadership, not just individual leader skills.

Outcomes assessments of leadership education programs on college campuses have shown that a multidimensional approach to leadership education programs can be particularly powerful. McKim et al. (2015), in a study of students' perceived outcomes following involvement in an interdisciplinary leadership minor, found positive effects of formal education on students' leadership. This formal program was found to positively impact students' ability to work and learn with others and navigate diverse values and opinions as a result of collective learning processes integrated into the leadership curriculum. Additionally, within the domain of leadership development at the individual level, two themes emerged as input variables affecting leadership development: self-awareness and self-reflection, and personal relevance to life and goals (McKim et al., 2015). Activities perceived as most effective for developing leadership practices were those which allowed for application of leadership concepts. Additionally, students identified opportunities to use new information in extracurricular settings. Development in leadership skill areas aligned with personal values and strengths were particularly impactful aspects of this leadership education program.

Combining opportunities to connect personal goals and values, literature, and practice are cornerstones of effective leadership education. Reflection, a critical aspect of leadership learning, assists students in connecting the dots (Volpe White at al., 2019). White and Guthrie (2015) found integrating reflection into leadership education programs leads to increased self-awareness, better relationships with others, and increased confidence in self, touching on the multi-dimensional impacts of leadership education. At both the individual and inter-relational levels, leadership education involving reflection and experiential learning was noted as particularly impactful, supporting the call for application and practice as part of leadership education programs. In order to support holistic leader development, leadership educators work to create meaningful environments to encourage leadership learning through both formal and informal education, honoring diversity of students, and their values (Beatty \& Guthrie, 2021). 


\section{Leadership and Values}

A holistic approach through both formal and informal educational environments has the potential to facilitate interpersonal and intrapersonal leadership education, resulting in individual values discovery. Dalton and Crosby (2011) assert leadership programs contribute to character education in many ways, such as, combating dangerous behaviors, promoting positive social attitudes and behaviors, encouraging academic and intellectual values, promoting holistic development including values clarification, and encouraging civic responsibility. Dalton (2015) expanded on these ideas, stating that ethical failures can promote moral growth, moving students toward engagement in ethical leadership practices. In these instances, students face new ideas, values, and ethical challenges once in the college environment due to insufficient knowledge about how approach moral dilemmas, peer pressures, and self-interest behaviors. Dalton (2015) asserted as students engage in leadership learning, ethical failures can lead to opportunities to recognize and evaluate peer culture, reveal information about their inner selves and values, and programs encourage students to think forward to avoid ethical failures through action in the future. Leadership education programs can assist students in moving toward ethical leadership in both the relational and individual domains. Aligning decisions with moral values in times of conflict are cornerstones of ethical leadership development (Brown \& Treviño, 2006; Fritz \& Guthrie, 2017).

Several researchers have posited the link between values, identity, and self-awareness can become increasingly integrated through the practice of leadership (Guthrie \& Jenkins, 2018; Komives et al., 2005; Lord \& Hall, 2005; Schwartz, 2015). Leadership education in a group is particularly powerful, as much of ethical leadership work is grounded in social learning theory, reflective of the relational, collaborative nature of leadership learning environments (Schwartz, 2015). Schwartz (2015) found in an extensive review of literature, students who act ethically as leaders have a strong sense of their ethical values, strong desire to act upon them, and strong will to deal with ethical challenges that present themselves in daily life, aligning leadership activities with their personal values.

Research on college student leadership development has found values are consistently applied as students enter high levels of leadership development. Komives et al. (2005) touch on the importance of values in leadership development. In the leadership identity model (LID), the researchers used a grounded theory approach to outline a five-stage process of leadership development in college students. The researchers found in stage four, awareness of interdependence, and the transition to stage five, participants began to desire alignment of their personal and organizational values in relation to their leadership work. This was amplified in stage five, Generativity, as students developed an integrated sense of self while balancing this with group influences. Participants were found in this stage to, "identify beliefs and values embedded in their actions led to an articulation of their passion for causes, for change, and for long-term personal goals" (Komives et al., 2005, p. 411). In one of the most widely accepted models of student leadership development, values and integrity were found to be central to realization of integration and synthesis of leadership development, in which students perceived an integrated view of self and others in leadership contexts (Komives et al., 2005). Embedding values into action was found to be possible as part of leadership learning in this theoretical model, and as program outcomes.

Values play an important role in ethical action in leadership situations (Fritz \& Guthrie, 2017). Illies and Reiter-Palmon (2008) explored the role of personal values in destructive, unethical leader decision making and problem solving, collecting data from 160 undergraduate students engaged in problemconstruction and role-playing exercises from a leadership perspective. The researchers measured individual differences in decision-making and problem-solving using Schwartz's values inventory. Illies and ReiterPalmon (2008) found that when posed with leadership situations, students with prominent self-enhancement values tended to engage in destructive decision-making and problem-solving, valuing power, whereas students who had prominent self-transcendence values less likely to engage in destructive behaviors, valuing universalism and relational relationships. Overall, personal values systems were found to have a strong influence on behavior in experimental leadership situations. As Illies and Reiter-Palmon (2008) stated, "these results suggest that leaders who act in a manner consistent with their values believe in the effectiveness of those behaviors and by in large are happy with those behaviors" (p. 266). These findings reinforce the need to address these issues in leadership education programs at the individual and group 
levels and efforts to better understand the impacts of leadership education programs on values-related behaviors.

\section{Leadership and Sense of Purpose}

As values are clarified, students also have the opportunity to connect personal values to their inner sense of purpose in life. Dalton and Crosby (2011) stated, "Moreover, many students come to college today with expectations that learning will not only prepare them for good jobs but also help them to explore their inner lives for purpose and meaning and to find their highest "calling" in the world" (p. 2). Leadership education programs are increasingly called upon to address the character and values development desires of students and institutions. However, little literature exists on the connection between leadership learning and development and one's sense of purpose. Nevertheless, Komives et al. (2013) found leaders who have a sense of purpose of able to sustain confidence during times of challenge. Leadership efficacy, the confidence in one's ability to be successful in leadership activities, is related to a clear sense of purpose at the individual and group level. This concept is strengthened by the work of Salisbury et al. (2012) in their investigation of leadership work on first-year college students. The researchers found students were able to demonstrate autonomy, responsibility, and self-confidence when engaged in group leadership activities, but this was directly connected to exhibiting a strong sense of purpose, ethics, and commitment to the organization. Although little literature on the connection between leadership education and a developed sense of purpose exists, it seems this may be a fruitful area for further understanding as leadership learning at both the individual and relational levels are impacted by this construct.

\section{STUDY CONTEXT: LEADERSHIP CERTIFICATE}

Studies of leadership programs have found engagement in leadership activities during college can have positive impacts on a range of student outcomes (Astin \& Astin, 2000; Cress et al., 2001; Beatty \& Guthrie, 2021). The leadership certificate in this study is an 18-credit interdisciplinary program which prepares students for leadership in multiple contexts. It provides an environment designed to foster student development and is based on a seamless learning model, where students engage in learning both inside of and outside of the classroom environment, created on a foundation of community building, education, and reflection (Guthrie \& Bovio, 2014; Guthrie \& Jenkins, 20187). The student population enrolled in the certificate is diverse (in regard to gender, age, background, major of study, year in school, etc.). While enrolled in the certificate, students engage in multiple collaborative projects and are encouraged to engage in dialogue during class time, as well as interact with faculty on an individual basis. This program uses reflection, theory-to-practice, experiential learning, and service-learning projects to frame leadership learning within the context of social change.

The certificate program includes four major learning outcomes intended to guide curriculum. These learning outcomes include 1) gaining theoretical knowledge of leadership theory; 2) increasing selfawareness through personal reflection; 3) increasing leadership skill development; and 4) the ability to apply theory-to-practice in multiple contexts. By participating in the program, the goal is that students will gain knowledge and skills which impact their leadership as an individual, in partnerships, in groups, and in their communities.

Established learning outcomes allow for the development of students' leadership capacity while encouraging discovery and clarification of values, ethics, civic engagement, and personal responsibility. A critical aspect of leadership learning is reflection and making meaning from experiences (Guthrie \&

Bertrand Jones, 2012; Volpe White et al., 2019). The inclusion of reflection throughout the certificate contributes to student development which allows program participants to synthesize and make meaning of their leadership knowledge and experiences. This is evident in all certificate courses, in which students are asked to reflect, often through weekly reading critiques. These critiques ask students to specifically apply their course readings to their own lives. It encourages students to make meaning of all their leadership learning. This ranges from courses taught from a different perspective to experiences outside of the classroom that contributed to their understanding of leadership. 


\section{METHODOLOGY}

The methodology employed for this study was qualitative in nature, leveraging the strengths of semistructured personal interviews. This choice was made to allow the researchers to respond to new information provided by participants, more deeply understand participant perspectives, and to incorporate ideas as the emerged both within and between interviews (Merriam, 2009).

Participants were recruited using enrollment information maintained by the leadership certificate. Only individuals who had completed all certificate requirements, had earned their intended undergraduate degrees, and had been either working or in Graduate School for at least two years were included in the recruitment efforts. Initial recruitment yielded 53 potential sample members, who were contacted. Of the 23 participants in the final sample, 18 were female and 5 were male.

The interview protocol was constructed taking into consideration the goals and objectives of transformative and adaptive leadership models, which were foundational to the certificate, as well as the stated learning objectives of the leadership certificate. Interviews were conducted in-person, over the phone, and via remote technologies by the principal investigator, three doctoral students, and one student affairs administrator. Interviews lasted between 20 and 113 minutes, depending on how much information the participant shared.

All interviews were audio recorded, and the recordings were transcribed by a contracted service. Interview transcripts were provided to both interviewers and interviewees for member-checking purposes. Member-checked transcripts were imported into NVivo 11, and coded using open, axial, and selective coding procedures in accordance with the suggestions offered by Miles et al. (2014) and in conjunction with a constant comparative method (Glaser, 1965).

\section{FINDINGS}

Through our data analysis, it became clear that leadership learning among certificate alumni had an impact on their character development by influencing personal values, as well as their sense of purpose. Participants discussed their values, as well as their life-calling or action-oriented perspective to larger purposes of goals - what we have termed "Sense of Purpose". Along both dimensions, participants' remarks reflected a variety of social, personal, or psychological conditions under which their characters developed as well as specific examples of how these character elements manifested in their lives. For each participant chosen, the expression of their personal values, as well as their sense of purpose will be highlighted:

\section{Emma}

After graduation, Emma went on to earn a master's degree in international development outside of the United States. Emma was working for a federal agency based in Washington, D.C. during her interview.

\section{Emma's Values}

As the chronologically oldest selected sample member, and the one who had been out of college the longest, Emma's account benefitted from having the most amount of time to reflect on the development of her values. She specifically enumerated building strong support systems and networks as core components of her personal values. In addition, she denoted valuing authenticity, education, and service in her academic, occupational, and social lives. While she indicated these orientations had remained stable through her certificate experience and beyond, she nonetheless remarked,

A few of them have changed, but I think for the most part they've stayed the same. Integrity is...one. I think it was... [an activity in] ...the capstone course, that just sparked something in me and I just realized that I wanted to keep them with me as a gentle reminder of who I am and what's important. It's something that I reevaluate from time to time, but for the most part, I've stayed the same. 
Emma continued this story by detailing a class activity where she was asked to write down her top 10 values and reflect upon what they meant to her at the time. She continued to carry the list with her, keeping it in her wallet even on the day she was interviewed. She described it as a, "...tangible reminder to look at it when I'm on the Metro and struggling, or feeling down or stressed, just remembering... what's important". As someone who identified as not being in exactly the career path she had intended, Emma's vision for the future wasn't as clear as she might have liked, but she conveyed a belief that staying true to her values would ultimately lead her to success.

\section{Emma's Sense of Purpose}

As Emma discussed her sense of purpose, the aforementioned values resurfaced. However, despite her time away from the certificate, and the plethora of life experiences she had detailed for us (going abroad for graduate study, an internship with a Washington DC-based non-governmental organization, volunteering with the Peace Corps, and working in her current position), it seemed as though she still had struggles with clarity in this area. When pressed about how internal purpose manifests in her life, she said,

I...want to have a relationship with my community in terms of volunteering, and a relationship with friends or family. So, recognizing that is important to me... [it] is a lesson that I'm really glad I learned. I started to learn it in Peace Corps but have tried to maintain because it hasn't been easy in D.C...

It seemed clear Emma's her sense of purpose was deeply rooted in her values, and that those values became clearer by participating in the leadership certificate. While she may have been balancing what is important in her life, she appeared to be well on her way from learning to living leadership.

\section{Jules}

Jules was working as an entry-level student affairs professional at small, private institution of higher education in the southeastern United States when she was interviewed.

\section{Jules' Values}

Because of her work in student affairs, but the orientation of her office in particular, Jules' responses largely reflected the values found in the social change model of leadership (Astin et al., 1996). When asked about how firmly she had adopted the values of the model, she explained,

I think it's what keeps me grounded... it just made me realize that it's okay to not have everything figured out. But ...not having everything figured out means that I still need to hold true to my vision and values. Those need to be at the core of what I do, and everything else will sort of fall into place.

She continued by detailing how that particular perspective for her was a "huge risk" which took a "leap of faith" to embody. She described knowing where she wanted to go in life, and shared her belief that, "....as long as I stick to those, everything else will be okay".

She furthered her comments by intimating the certificate's courses offered her "...one of the first times I'd ever been asked what are your values, what do you truly value? That was a huge moment for me because I never remember thinking about that before". Jules revisited this theme of introspection repeatedly during our conversation, especially in the articulation of her personal values. Undoubtedly, Jules found in the leadership certificate the time, space, and grace to investigate her values and begin to formulate notions about how those values would not only shape her leader development but her character development as well. 


\section{Jules' Sense of Purpose}

More so than many of our other respondents, Jules talked about the intersection of values with various aspects of life in her developing a sense of purpose. She described this intersection as a "collision" where, "personal and professional life came together and where I really started to understand... where my purpose needs to develop". It became clear she was still grappling with issues related to finding her life's calling but had started to develop a stronger sense of what would guide her through such a challenge. We asked her about how this "collision" framework showed up in her work as a student affairs administrator and she offered the following account:

I think by students seeing how committed I am...it inspires that light in them....and I think...a big piece of leadership education is that regardless of what your major is, what your career goal is, what your passion is, do something and do good with it. That's something we talk a lot about ... [with students] ...that it doesn't matter at the end of the day what you want to do. But if you use that for good and to make some sort of change, then I say you're a success and you're living with purpose.

Jules was clearly leveraging her leadership learning, with specific focus on the social change model of leadership, as she moved toward living leadership. She had had adopted many of the values of the social change model, despite still balancing which ones were most important and how to live those values fully. We got the impression she benefitted significantly from the non-judgmental climate of the leadership certificate, going so far as to attempt to recreate those feelings of acceptance and inclusion in her own work with undergraduates. While she nonetheless may have still been working through the formulation of her larger life goals, it was plainly apparent through her accounts that her experiences in the leadership certificate had been foundational to her thinking and planning.

\section{Xavier}

When Xavier was interviewed, he was both a graduate student in higher education and a graduate assistant at a large, research university in the Southeastern part of the United States. Xavier graduated with a Bachelor of Science in English education, and much of the interview centered on his first year of teaching.

\section{Xavier's Values}

When asked about his values orientation, Xavier described living a life centered on bravery and vulnerability. Much of his discussion was couched in his identity as a gay man; Xavier was both proud of his sexual identity, but recognized it also made him a target for bias and discrimination. Ultimately, Xavier placed his relationship with bravery and vulnerability into the context of "authenticity" - what he identified as his "core value". He intimated during his year of student teaching, he often felt as though he couldn't be his authentic self in the classroom because of the relative lack of protection. He explained:

I knew that I was not allowed to be openly gay as a teacher in that school because I was not protected under the nondiscrimination policy. So the biggest cherry on top of the year was [when] I had one week left and I knew that I wanted to talk about it because my authentic self wouldn't let me leave this school without my students knowing fully who I was and for me being able to teach them authentically as myself for an entire week.

Through this story, Xavier helped us understand how his values of bravery, vulnerability, and authenticity came together in his student teaching experience. When asked where the motivation to lead an authentic life came from, he immediately started describing experiences he had within the context of the leadership certificate, giving us the sense his leadership learning experiences fueled his authentic way of being. Most directly, he attributed his past and current success to his ability, "...to understand change is a good thing. Conflict is a good thing. All these things are good things" as a result of learning about change and transition 
through the certificate. As such, we began to understand Xavier's values and his future vision of "change as a potential positive" as a product of his leadership learning.

\section{Xavier's Sense of Purpose}

Xavier talked about his sense of purpose both during his time as an in-training teacher, but also in his then-current role as a graduate assistant. As a teacher-in-training, Xavier described how his intent to develop his students trumped the resistance he faced from supervisors:

... some of my administrators disagreed with some things that I taught or at the end, the last week, whenever I had my coming out day, they were not pleased with that either but I had to remind myself again what my purpose was for being there. Isolating whatever that purpose was and really focusing on it gave me more faith...my goal for coming to that school was not to make all my students pass the SAT. That's great and I'm sure they did fine but my goal was...to expand their horizons and to really present them a way of life that they maybe they hadn't heard before.

Xavier's dedication to developing whole students, and not just those who achieve academically, even in the face of administrative pressure undoubtedly came across during his interview. The underlying purpose didn't end there, however. When encouraged to provide more examples of his purpose in practice, Xavier returned to his aforementioned values in telling a story about his current role:

The vulnerability piece ...is ...sharing of myself and being the one to model what that looks like. If I'm expecting the students to ... achieve maximum growth throughout the year by reflecting parts of their personal life that maybe intersects with why they're leading ...I have to show them what it looks like to reflect on my experience. I have to show them what it looks like to talk to other people about my experience... That's how I can create these environments where everybody feels welcome to be themselves. The impact is just increased tenfold because of that.

It seems obvious Xavier took his own character development and the character development of the students he worked with very seriously. He was able to recount well-articulated strategies for the authentic life he wished to live and tactics for role modeling bravery and vulnerability with those under his charge. Perhaps it was because he was so recently involved with the certificate that these experiences remained salient in his mind, however; his stories left no doubt the development of his character was profoundly influenced by his leadership learning experiences and others may have benefitted from the insights he had acquired through those experiences.

\section{Ike}

Ike was both our youngest alum and the most recently graduated at the time of the interviews. Employed by a mid-sized research institution in the Southeastern part of the United States, Ike was planning to transition out of his current role into full-time graduate study in computer science at the time of his participation in this study.

\section{Ike's Values}

Ike had a difficult time articulating his values when asked. However, he did show signs of engaging with his own challenges and seemed to understand the role of the certificate and its surrounding context in his contemplations. Ike detailed his conflict, "I think it would be really nice if you could just define your values once and be done with it ...But it's not how things work..." Ike continued his explanation by describing his values clarification process as one of "constant exploration" and reevaluation based on other factors in his life, such as his job demands and desire to begin full-time graduate study. He also expressed 
a deep desire to have more time to engage in this process as life as a working individual did not provide him with as much flexibility as his recent student status in wrestling with issues of values.

\section{Ike's Sense of Purpose}

Ike's job at the time of interview was to manage the progression of undergraduate students through his academic unit within his university. As such, he described the advising role inherent to assisting students with satisfactory progress and career development. As someone who was in transition regarding his own academic and career goals, Ike's sense of purpose was deeply connected with his daily job responsibilities. He described his approach to his work by providing some general context:

...exploratory advisors take an approach of values, interests, skills. ...And so I try to talk with students about experiences that are significant to them, people who they've seen who are in positions and are able to do things that they would like to do, and try and fill in the pieces in between there. ...I try to remind students that it's really - the weight of the different experiences as far as the degree that you pursue and maybe your extracurricular experiences may not be as disparate as you think. ...I would say it's probably my extracurriculars have formed a lot more of where I ended up than my degree.

When asked to clarify what he meant by "extra-curriculars", Ike included the certificate as part of his discussion. It was not entirely surprising that Ike, as the youngest and most recent graduate, was still clarifying his own values, setting more goals, and had a sense of purpose linked to the activities of his job. It was heartening to hear his leadership learning experiences had at least provided some basic direction regarding how he might go about establishing goals and leading a lifestyle aligned with his most dearly held principles. Ike would have certainly benefitted from more time and space to engage in these processes, but his story illustrates what others may face early on the transition from college leadership learning to post-college leadership living.

\section{DISCUSSION AND IMPLICATIONS}

The primary intent of this study was to determine what leadership certificate students learned from their experiences in the program and how they leveraged leadership learning in their post-college lives. In accordance with the extant literature, the leadership certificate focuses on the transmission of knowledge, development of skills, and values discovery vital to the effective practice of leadership. This learning also informed the character development of certificate alumni most directly through the values identification and discovery process and the refinement of individuals' sense of purpose.

However, within the leadership certificate, the learning environment seems to be just as important as the content being taught. A major strength of the leadership studies certificate is the provision of space and opportunities to have conversations about personal missions, visions, and values as well as the facilitation of conversations about individuals' sense of purpose. Being able to have these conversations in a nonjudgmental way adds to students' leadership learning and character development while they are enrolled and after college. Dalton and Crosby (2011) found that higher education is increasingly focused on character and moral development, and realignment of institutional missions integrating ethical values is a desired educational outcome. Providing a space for value discovery through leadership learning fills a gap present in many students' academic studies.

Participants in this study were still very early in their careers. The evidence of their development we have uncovered here, however, gives confidence that their leadership learning and their attendant character development fundamentally informs their progression from leadership learning to living leadership regardless of how their occupational choices have taken shape and the ways in which their career trajectories may change over time. Leadership education programs have the potential to help students connect their personal values and sense of purpose, integrating self and action throughout their life journey beyond college. 


\section{CONCLUSION}

Values discovery and sense of purpose are critical components of leadership learning and character development. As an experiential, interdisciplinary field of study, leadership education provides a learning environment in which students can benefit from reflection on values and supporting integration of self and action in order to connect it to their life journey. By providing students with opportunities to discover their values and connect it to their life beyond college, both in professional and personal contexts, they can move from leadership learning to living leadership through their values and sense of purpose. By prioritizing values discovery in leadership education, we can increase opportunities for meaningful student learning and hopefully develop graduates with a strong sense of purpose to lead ethically for a better world.

\section{REFERENCES}

Antonacopoulou, E.P., \& Bento, R.F. (2003). Methods of 'learning leadership': Taught and experiential. In J. Storey (Ed.), Current Issues in Leadership and Management Development. Routledge.

Astin, A.W., \& Astin, H.S. (Eds.). (2000). Leadership reconsidered: Engaging higher education in social change. W.K. Kellogg Foundation.

Astin, H.S., Astin, H., Boatsman, K., Bonous-Hammarth, M., Chambers, T., \& Goldberg, S. (1996). A social change model of leadership development: Guidebook(Version III). Higher Education Research Institute, University of California, Los Angeles.

Beatty, C.C., \& Guthrie, K.L. (2021). Operationalizing culturally relevant leadership learning. Information Age Publishing.

Brown, M.E., \& Treviño, L.K. (2006). Ethical leadership: A review and future directions. The Leadership Quarterly, 17(6), 595-616. https//doi.org/10.1016/j.leaqua.2006.10.004

Cress, C.M., Astin, H.S., Zimmerman-Oster, K., \& Burkhardt, J.C. (2001). Developmental outcomes of college students' involvement in leadership activities. Journal of College Student Development, $42(1), 15-27$.

Dalton, J.C. (2015). Making moral mistakes: What ethical failure can teach students about life and leadership. In A.J. Schwartz (Ed.), New Directions for Student Leadership: No. 146. Special Issue: Developing Ethical Leaders (pp. 71-79). Jossey-Bass. https://doi.org/10.1002/yd.20136

Dalton, J.C., \& Crosby, P.C. (2011). Core values and commitments in college: The surprising return to ethics and character in undergraduate education. Journal of College and Character, 12(2), 1-4. doi: $10.2202 / 1940-1639.1796$

Dugan, J.P. (2006). Involvement and leadership: A descriptive analysis of socially responsible leadership. Journal of College Student Development, 47(3), 335-343. https://doi.org/10.1353/csd.2006.0028

Dugan, J.P., \& Komives, S.R. (2007). Developing leadership capacity in college students. College Park, MD.: National Clearinghouse for Leadership Programs.

Eich, D. (2008). A grounded theory of high-quality leadership programs: Perspectives from student leadership programs in higher education. Journal of Leadership \& Organizational Studies, 15(2), 176-187. https://doi.org/10.1177/1548051808324099

Fritz, M.R., \& Guthrie, K.L. (2017). Values clarification: Essential for leadership learning. Journal of Leadership Education, 16(1), 47-63. https://doi.org/10.12806/v16/i1/r4

Glaser, B.G. (1965). The constant comparative method of qualitative analysis. Social Problems, 12(4), 436-445. https://doi.org/10.1525/sp.1965.12.4.03a00070

Guthrie, K.L., \& Bertrand Jones, T. (2012). Teaching and learning: Using experiential learning and reflection for leadership education. In K.L. Guthrie \& L. Osteen (Eds.), New Directions for Higher Education: No. 140. Developing students' leadership capacity (pp. 53-64). Jossey-Bass. https://doi.org/10.1002/ss.20031

Guthrie, K.L., \& Bovio, B. (2014). Undergraduate Certificate in Leadership Studies: An opportunity for seamless learning. Journal of College and Character, 15(1), 25-32. https://doi.org/10.1515/jcc2014-0004 
Guthrie, K.L., \& Jenkins, D.M. (2018). The role of leadership educators: Transforming learning. Information Age Publishing.

Guthrie, K.L., \& Osteen, L. (2012). Editors' notes. In K.L. Guthrie \& L. Osteen (Eds.), New Directions in Student Services: No. 140. Developing students’leadership capacity (pp. 1-3). Jossey-Bass. https://doi.org/10.1002/ss.20027

Guthrie, K.L., Bertrand Jones, T., Osteen, L., \& Hu, S. (2013). Cultivating Leader Identity and Capacity in Students from Diverse Backgrounds. Jossey-Bass.

Illies, J.J., \& Reiter-Palmon, R. (2008). Responding destructively in leadership situations: The role of personal values and problem construction. Journal of Business Ethics, 82(1), 251-272. https://doi.org/10.1007/s10551-007-9574-2

Komives, S.R., Longerbeam, S.D., Owen, J.E., Mainella, F.C., \& Osteen, L. (2006). A leadership identity development model: Applications from a grounded theory. Journal of College Student Development, 47(4), 401-418. https://doi.org/10.1353/csd.2006.0048

Komives, S.R., Lucas, N., \& McMahon, T.R. (2013). Exploring leadership: For college students who want to make a difference (3rd ed.). Jossey-Bass.

Komives, S.R., Owen, J.E., Longerbeam, S.D., Minella, F.C., \& Osteen, L. (2005). Developing a leadership identity: A grounded theory. Journal of College Student Development, 46(6), 593-611. https://doi.org/10.1353/csd.2005.0061

Lord, R.G., \& Hall, R.J. (2005). Identity, deep structure and the development of leadership skill. The Leadership Quarterly, 16(4), 591-615. https//doi.org/10.1016/j.leaqua.2005.06.003

McKim, A.J., Sorensen, T.J., \& Velez, J.J. (2015). Identifying inputs to leadership development within an interdisciplinary leadership minor. Journal of Leadership Education, 14(2), 51-64. https://doi.org/10.12806/v14/i2/r4

Merriam, S.B. (2009). Qualitative research: A guide to design and implementation. Jossey-Bass.

Miles, M.B., Huberman, A.M., \& Saldana, J. (2014). Qualitative data analysis: A methods sourcebook. Sage Publications.

Northouse, P.G. (2021). Leadership: Theory and practice (9th ed.). Sage Publications.

Roberts, D., \& Ullom, C. (1989). Student leadership program model. NASPA Journal, 27(1), 67-74. https://doi.org/10.1080/00220973.1989.11072136

Roberts, D.C. (2007). Deeper learning in leadership: Helping college students find the potential within. Jossey-Bass.

Salisbury, M.H., Pascarella, E.T., Padgett, R.D., \& Blaich, C. (2012). The effects of work on leadership development among first-year college students. Journal of College Student Development, 53(2), 300-324. https://doi.org10.1353/csd.2012.0021

Schwartz, A.J. (2015). Inspiring and equipping students to be ethical leaders. In A.J. Schwartz (Ed.), New Directions for Student Leadership: No. 146. Special Issue: Developing Ethical Leaders (pp.516). Jossey-Bass. https://doi/org/10.1002/yd.20136

Thompson, D.L. (1991). Introduction: Academe - the institutions and individuals: An introduction to a discussion of morals in higher education. In D.L. Thompson (Ed.), Moral values and higher education: A nation at risk (pp. 1-10). State University of New York Press.

Thompson, M.D. (2006). Student leadership process development: An assessment of contributing college resources. Journal of College Student Development, 47(3), 343-350.

Volpe White, J.M., Guthrie, K.L., \& Torres, M. (2019). Thinking to transform: Reflection in leadership learning. Information Age Publishing.

White, J.V., \& Guthrie, K.L. (2015). Creating a meaningful learning environment: Reflection in leadership education. Journal of Leadership Education, 15(1), 60-75. https://oi.org/1012806/V15/I1/R 